\title{
The Potential of the Senses in Al-Quran as the Basic Elements of the Human Physic and Its Application in Learning
}

\author{
Sawaluddin \\ Institute of Islamic Religion (STAI) of Rokan Bagan Batu \\ Rokan Hilir Street \\ Bahtera Makmur, Bagan Batu Riau, Indonesia \\ sawaluddinregar@ymail.com
}

\author{
Munzir Hitami, Zikri Darussamin, Sainab \\ UIN Sultan Syarif Kasim Riau \\ Riau, Indonesia \\ mzr.hitami@gmail.com, zikri.darussamin1961@gmai.com, \\ mariyahmarwahsiregar@gmail.com
}

\begin{abstract}
The Quran explains, that the physical aspect, the human has, that form which can be in the form of the body senses. This research aims to analyze the potential of senses in AlQuran contained in the human self as the basic elements of the human Physic and its application in the Study of Islamic religious education. This research is Library research using the method of thematic tafsir, it is collecting the ayat that talk about human senses, then determine the topic and perform analyze with using tafsir tahlili analyze, which then draw conclusions. The results of this research is a senses potential form of Sensory hearing, aslsam, al-bashr, and al-dhuq. As for the Potential development of the senses, is through Tafakur, Taddabbur, planting of good planting belief and the use of methods, techniques and learning strategies that are in accordance with the lesson taught, are directional, phased and continuous improvement.
\end{abstract}

\section{Keywords-al-quran; application in learning; the potential}

\section{INTRODUCTION}

In the view of Islam, man is a creature of God who served as the Caliph on earth. Allah has informed the angels that $\mathrm{He}$ will create a man entrusted with the task of becoming Caliph, as written in the Qur'an letter of al-Baqarah verse 30:

It means: Remember when your Lord said to the Angels: "I am about to make a caliph in the land." They say: "Why would You make the Caliph of the earth the one who will cause harm to him and shed blood, by praising You and sanctifying You?" The Lord said: "I know what you do not know." [1].

In addition to human beings as caliphs, they also include pedagogic creatures that are God-born creatures bring the potential to be educated and educated as in the Qur'an an-Nahl verse 78: It means: And Allah took you out of your mother's belly in a state of not knowing anything, and He gave you hearing, sight and heart, that ye may be grateful [2].

In the Qur'an an-Nahl verse 78, Allah implies that the potential (hearing, sight, and heart) that has been bestowed on it needs to be fostered in an optimum and integrated manner. Because with that potential he can learn from the environment, nature, and the community where he lives in the hope that to become a complete adult human.
An-Nahlawi adds a comment to the verse's explanation that if the potential of hearing, sight, and heart are continuous, then a science which God will grant to humankind will bring man to the happiness of the world and the hereafter. It focuses on optimizing the function of these three potentials to science by stating that hearing functions as a scientific observer that has been found by others, the vision has the function to develop science by adding the results of research and assessment of it, and the heart of the duty member sih science from all the stains and dung [3].

One of the steps or efforts that can be done to achieve and harmonize the potential of learners is to develop the potential possessed by students through the process of education and learning using the concepts of Indra's potential development, as the guidance in Qur'an.

Education as a conscious effort undertaken by family, community and government, through counseling, teaching, and training activities, which take place in school and outside school throughout life, to prepare learners to play a role in various environments appropriately in the future come. Education becomes a very strategic pillar in the process of internalization and socialization of values because education is directly related to the human aspect in which contain the forces that must be stimulated, so that the potentials have an optimal growth, especially in facing various forms of challenges in the future [4]. Delors argues that in the face of future challenges, humanity sees education as something that is desperately needed in its quest for the ideal of peace, liberty and social justice [5].

Based on the above explanation, it needs to be studied further, whether the Qur'an in developing human potential, especially the potential of Indra in learning comprehensively.

\section{LITERATURE REVIEW}

\section{A. The Potential of the Human Senses}

The senses are a means to feel, smell, hear, see, touch, and feel something instinctively. In another sense, the sense is a vital functional tool or which is required by every human being according to its limitations [6]. In English, the senses are called 
sense, which literally means feelings or feelings. Chaplin senses sense to sense, feeling, senses, appreciation, observation, and understanding [7].

Humans and animals that function to absorb the image of an object so that the object is stored in memory and can manifest by expression or writing. Indra has a very meaningful contribution in shaping knowledge, including quality or truth and mistakes in understanding something. Sensory errors in absorbing information can form misper captions, views, understandings, or judgments of an object and the problems it absorbs. There are two internal parts of the human being that are capable of entering something of the sense device, i.e. the mind and the sense. Both of these cases became the driving force of human behavior including the impulse to speak [8].

\section{B. Minds of the Human Indra}

The sensory apparatus is the organs of the human body that are able to receive excitatory from the outside and process it in the brain before it is translated into the work of that organ. Humans have 5 sensory devices including the eyes, skin, tongue, ears, and nose. This sense device will only function if there is no abnormalities in the organ, the connecting nerve between sensory and central nervous system, and human central nervous system.

The five sense devices that exist in the human body itself has its own function. The eye has a function as the sense of sight, the tongue has a function as the sense of taste, the skin as the sense of touch, the ears as the sense of hearing, and the nose as the sense of smell [9].

\section{The Function of the Human Senses}

Every living being on earth is created side by side with nature, because nature is essential to the survival of living beings. Therefore every living creature, especially man must be able to maintain the balance of nature. To be able to maintain the balance of nature and to be able to recognize the changing environment, God gives the senses to every living being [10].

This senses serves to recognize any changes in the environment, both inside and outside the body. The senses that exist in living things, have special receptor cells. These receptor cells function to recognize the environmental changes that occur. Based on its function, these receptor cells are divided into two, namely interoreseptor and eksoreseptor [6].

This interorepeptor serves to recognize the changes that occur in the body. Interoreseptor cells are present in muscle cells, tendons, ligaments, joints, blood vessel walls, gastrointestinal walls, and so on. These cells can recognize the various changes that exist in the body such as pain in the body, decreased oxygen levels, glucose levels, blood pressure down /rise and so forth. Ecorreceptor is the opposite of intero repeptor, a functional eksoreseptor to recognize environmental changes that occur outside the body. Which include eksoreseptor namely: 1) The sense of sight (eye), the senses serve to recognize environmental changes such as rays, colors and so forth. 2) The sense of the listener (ear), the senses serve to recognize changes in the environment such as sound. 3) The sense of touch (skin), the senses serve to recognize environmental changes such as heat, cold and so forth. 4) Taste senses (tongue), the senses serve to recognize environmental changes such as tasting sweet, bitter and so forth. 5) The sense of smell (nose), the senses serve to recognize environmental changes such as recognizing / smelling [6].

\section{The Human Senses in Learning}

Education is a must that is given to the students. Students as human beings that have the potential to be nurtured and guided by the mediation of teachers. The potential of students who are latent need to actualisation so that students no longer be said as an animal educable, which is a kind of animal that allows to be educated. However, he must be regarded as an absolute human being, because students are human beings who have the potential to be a force in order to become a capable moral man [11].

Basically every child is equipped by God with seeds of ability (potency) which when appropriate "seeding" will grow and develop into real skills that must exist in a devoted servant of God, and who served as God's mandate on earth, be a regulator and coach the virtues of living together on this earth according to the line that has been determined by God, so that later will get employment and the need for a reasonable life [12].

For the potential given by God to the child is in the form of body, also equipped with spirit (soul / psychic) which has various potential and this is an inseparable unity. Physical potential works because it obtains the energy of the spirit (psychic), otherwise the psychic potency which is driven by its own energy functions only in its unity with the body (body). [13].

Zakiah Daradjat himself said that if the potential is not developed, undoubtedly it will be less meaningful in life. Therefore, it is necessary to develop and develop it always in business and educational activities. With education and teaching the potential can be human. Although the born child is like clean white paper, the net has nothing and although it is born with a self-evolving nature. But the development will not advance, if not through a certain process, namely the process of education. The obligation to develop that potential is a burden and a human responsibility to God. The possibility of developing that potential means, that man may be educated, as well as possible that one day he will educate. This shows that the potential or ability of the child needs other people to encourage and direct it so that the potential can grow and develop optimally, so that later can be useful for his life. In other words, that education has a very important role in order to develop aspects that exist within the child, whether it involves the physical aspect as well as the spiritual aspect [14].

This is where education plays a role in order to help develop these potentials to be optimized as possible. Because education is a part of human life, it is absolutely necessary [15].

\section{METHODOLOGY}

This research is designed in the form of library research or library research using various sources of literature as a source 
of research data. Research Library or Library research is a study related to the thinking of a figure who in a certain time, cultural conditions, society at that time, along with the document, methodologically the approach used is the approach of interpretation [16].

The object of this study is the Qur'an. In line with that, the research method used is the method of interpretation of the Qur'an [17]. Based on the explanation, then the steps undertaken in thematic interpretation method are as follows [18]: a) Determining the topic of discussion or choosing the issue of the Qur'an to be studied; b) Collect and establish the verses that address the issues or problems that have been set; c) Arrange the sequence of verses according to the period of descent, for example Makiyah takes precedence over the verse Madaniyah; d) This study of interpretation requires the help of tahlili commentary on various aspects of the verse concerning asbab al-nuzul, munasabah and verse, knowledge of verse, etc.; e) Arrange the discussion in one frame; f) Complete the discussion with the traditions concerning the issue under discussion; g) Study all selected verses by compiling all the same verses of meaning, or compromise between 'am (general) and distinctive (special), mutlaq with muqayyad, or contradictory, so that all meet in an estuary [19].

\section{RESULTS AND DISCUSSION}

Based on the results of research conducted, it can be concluded as follows:

\section{A. The Potential of the Human Senses in the Qur'an}

The body is a human substance consisting of the structure of a physical organism that is sensory. The human physical organism is more perfect than the physical organisms of other beings. Al-Qur'an explains, that, humans have the physical aspect, that form can be in the form of body indra. The word aljism (body) is mentioned in the Qur'an only twice. First, in a single form, that is when talking about Thalut. Secondly, with the plural, when speaking of the hypocrites as it is revealed in the Qur'an letter, al-Baqarah: 247. This means: Their Prophet told them: "Allah has appointed Thalut to be your king." They replied: "How did Thalut rule over us, whereas we have more right to control the government therein, while he was not given enough wealth?" The Prophet: "Allah has chosen your king and granted him the knowledge of the Broad and the mighty body." God gives the government to whom $\mathrm{He}$ will. And Allah Almighty His grant is omniscient [20].

In the Qur'an letter, al-Munafiqun: 4 is described as follows: Meaning: And when you see them, their bodies make you wonder. And if they say you listen to their words. They are as if the wood is leaning. They thought that every loud shout was directed against them. They are the enemy (the truth) so beware of them; may Allah destroy them. How are they to be turned away (from the truth)? [21].

However, many other verses refer to the physical matter, usually represented in the word "world," which shows the things that are necessary for the body. Integral, these tools are used by the senses as data seekers. Indra owned by humans, if exercises and sharpening for the functions will function well. The development of the function of the sense devices follows the direction of healthy physical growth with good maintenance and care. Man is placed on earth in the midst of God's other creatures. On the face of the earth man is entitled earned a living, and as a counterpart he was burdened with obligations both to God and to his fellow beings in the world. In this case there is no conflict between spirit and body, there is no contradiction of the world and the hereafter, and there are no things that destroy the delights of human enjoyment of God's gifts, thus confusing feelings and tearing up feelings. The attempt to obtain the nobleness is not an error of the hereafter. In the Qur'an, man is intact, inseparable between his body and his spirit, inseparable between his mental and physical, and inseparable between his worldly affairs and his eternal affairs.

With true inspiration the Qur'an saves the human mind from the opposite way of thinking. Not only prevents the intellect from the conflicts arising from his duties and responsibilities, but also saves the human mind from the confusing conflicts in the face of two lives as taught by religion, the life of the world and the hereafter [8].

\section{B. Minds of the Human Indra in the Qur'an}

The term used by the Qur'an in mentioning the sense of perfection is al-sam'u. This word in the Qur'an, repeating 185 times in various forms of the word (sighat). In general, al-sam'u in the Qur'an has two meanings. First the term is used to describe the nature of God, it is one of asmā 'al-husnā, that is al-sam' (the all-hear). This is, for example, illustrated in the word of God fussilat letter (41) verse 36. The term the Koran uses to describe the sense of sight is al-bashr. This word, in the Qur'an with various sighat, repeats 139 times. As with alsam'u, the word al-bashr is also expressed in two senses; first al-bashr in the meaning of the nature of God, namely al-bashr (the all-seeing), and the two al-bashrs in the sense which God gives to man [22].

\section{The Function of the Human Senses in the Qur'an}

The Qur'an has clearly talked about man's encompassing senses, as a tool for humans to perceive information that exists outside of him. The senses discussed are hearing (al-sam '), sight (al-bashr), touch and sense of taste (al-dhuq) complete with its function: 1) The sense of sight (eye), the senses serve to recognize environmental changes such as rays, colors and so forth. 2) The sense of the listener (ear), the senses serve to recognize changes in the environment such as sound. 3) The sense of touch (skin), the senses serve to recognize environmental changes such as heat, cold and so forth. 4) Taste senses (tongue), the senses serve to recognize environmental changes such as tasting sweet, bitter and so forth. 5) The sense of smell (nose), the senses serve to recognize environmental changes such as recognizing / smelling [23].

\section{Development of the Human Potential in Learning According to Al-Qur'an the Human Senses in Learning}

The Qur'an has clearly talked about man's encompassing senses, as a tool for humans to perceive information that exists outside of him. The senses discussed are hearing (al-sam '), sight (al-bashr), touch and sense of taste (al-dhuq) complete with its function. 
In general can recognize the potential of Indra as panca Indra namely Indra which amounts to five. The potential that God gives to humans in the form of Indrawi's ability as the first potential fulfillment. Panca Indra is a communication window to know the environment of human life, so from here humans will get knowledge and knowledge.

This shows the physical nature of every individual there are physical potentials, if true, the development will be a workmanship. In the psychological aspect of each individual there are also psychological potentials that if true growers and developments will form scientific thinking skills in searching and discovering the truth of scientific workmanship, scientific and scientific minded, noble and noble ideals, strong-willed not be flexed even in pursuing and fulfilling those ideals, willingness to carry oneself to the very point that God wants, both in relation to God and in relation to fellow human beings or in relation to nature[24].

Each learning is done to produce the goal to be achieved. In developing the potential of the senses that chill is; a) Perception (perception) is concerned with the use of sense organs to capture signals that guide motion activity. b) Readiness (set) is to indicate the readiness to perform actions or mental and physical readiness to act. c) Guided movement (guided response), which is the first stage in learning complex skills such as imitation. d) The accustomed movement (mechanism) is concerned with the performance in which the learners' responses have become accustomed and movements with confidence and skill. e) Complex Movement (complex overt response), which is a highly skilled movement with very complex motion patterns; f) Adaptation of the pattern of adaptation, i.e. with respect to well-developed skills so that learners can modify the patterns of motion to match certain demands. g) Creativity (organization), which refers to the creation of new patterns of movement to adjust a particular situation or special problem [25].

Therefore, in the implementation of learning and developing the potential of Indra, appropriate materials and methods are needed in the learning process [26].

The method used in the development of the human potential according to al-quran is by using the Method of Coaching, Exercise Method, Investigation Method, Methods of Discussion / Dialogue, Questioning Methods, Problem Solving Method, Debate Method (al-Mujadalah), as shown below [26].

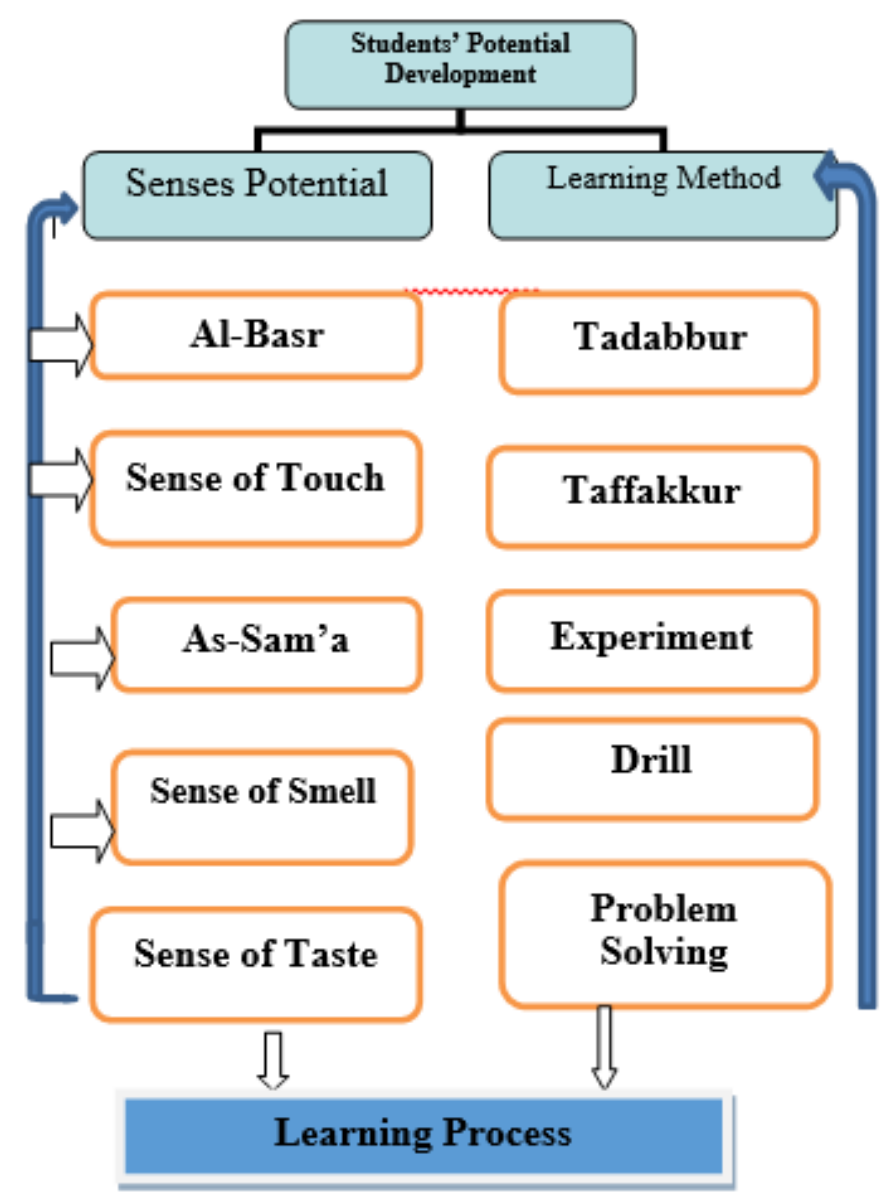

Fig. 1. Design of students potential development.

\section{CONCLUSION AND RECOMMENDATIONS}

\section{A. Conclusion}

The results of this research is a senses potential form of Sensory hearing, asl-sam, al-bashr, and al-dhuq. As for the Potential development of the senses, is through Tafakur, Taddabbur, planting of good planting belief and the use of methods, techniques and learning strategies that are in accordance with the lesson taught, are directional, phased and continuous improvement [25].

\section{B. Recommendations}

Based on the research that has been done writer, the authors provide suggestions as follows:

- For the government through the Ministry of Religious Affairs and the Ministry of National Education is expected to make this research as a consideration in suckling and developing the curriculum of education in Indonesia and especially the Islamic education curriculum.

- It is expected that the policy makers make this research as a reference in developing the potential of Indra students, at the level of basic education, so that the 
participants will grow into qualified students with all the potential that is owned perfectly and in balance.

- For teachers of basic education this study is expected to be a reference in developing the potential students in pursuit so that students grow into quality students with all the potential that is owned perfectly and balanced.

- Need further research to know the right materials and methods in the development of the three potentials Indra, in learners in learning.

\section{REFERENCES}

[1] Departemen Agama Republik Indonesia, Al-Qur'an dan Terjemahannya, Surabaya: Karya Utama, 1993, pp. 6.

[2] Departemen Agama Republik Indonesia, Al-Qur'an dan Terjemahannya, Surabaya: Karya Utama, 1993, pp. 375.

[3] Abdurrahman An-Nahlawi Pendidikan Islam di Rumah, Sekolah dan Masyarakat, Jakarta: Gema Insani Press, 1995, pp. 60.

[4] Silahuddin, "Konsep PendidikanMenurut Al-Ghazali (Tinjauan Filsafat Pendidikan)," Islamic Studies Journal, Vol 2, No 1, Januari- Juni 2014, pp. 150.

[5] Delors, Education: The Necessary Utopia Pengantar di dalam "Treasure Within" Report the International Commission on Education for the Twenty-firs Century, Paris: UNESCO Pubhlising, 1996, pp. 13.

[6] K.M. Yusuf, "Indra Manusia Menurut al-Qur'an dan Psikologi Kompensional: Suatu Kajian Perbandingan (Human Sense in the Qur'an and Comventional Psyehology: A Comparative Study)," Jurnal Hadhari, vol 6, no (2), Universitas Kebangsaan Malasyia, 2013, pp. 56-57.

[7] J.P. Chaplin, Kamus Lengkap Psikologi (terjemahan oleh: Kartini Kartono), 2002.

[8] Abbas Mahmud al-'Aqqad, al-Insan fi al-Our'an al-Karim, Kairo: Dar al-Islam, 1973, pp. 35.

[9] Ibn Sīnā, Abī Ḥasan Alī. Aḥwāl al-Nafs. t.tp.: cIsa al-Babi al-Halabi, 1952 .
[10] Ibn Sīnā, Abī Ḥasan Alī. Risālah fĩ al-Kalām `Alā al-Nafs al-Nātiqah t.tp.: cĪsā al-Bābi al-Halabi, 1952.

[11] S.B. Djamarah, Guru dan Anak Didik dalam Interaksi Edukatif, Jakarta: Rineka Cipta, 2000, pp. 52.

[12] B. Somad, Beberapa Persoalan dalam Pendidikan Islam, Bandung: alMa'arif, 1993, pp. 46.

[13] H. Nawawi, Hakekat Manusia menurut Islam, Surabaya: al-Ikhlas, 1993, pp. 236.

[14] S. Hariyadi, dkk., Perkembangan Peserta Didik, Semarang: Semarang Press, t.th., pp. 44.

[15] U. Munandar, Mengembangkan Bakat dan Kreativitas Anak Sekolah, Jakarta: Gramedia Widia Sarana Indonesia, 1992, pp. 26.

[16] M.A. Suryadilaga, Metodologi Ilmu Tafsir, Yogyakarta: Penerbit Terad, 2005, pp. 78.

[17] Abd al-Hayy al-Farmawi, Al-Bidayah fi al-Tafsir al-Mawdu'i. alQahirah: Dirasah Manhajiyah Mawdu'iyah, 1977, pp. 23.

[18] Zahir ibn Awad al-Alma'i. Dirasah fi al-Tafsir al-Mawdu'i li Al-Qur'an al-Karim, (Riyad: al-jami'ah Ibnu Sa’ud, 1404 H/ 1984 M, pp. 18.

[19] M.Q. Shihab, "Metode-metode Penafsiran Al-Qur'an". Dalam Azyumardi Azra (ed.) Sejarah dan Ulum Al-Qur'an. Jakarta: Pustaka Firdaus, 2000 Cet. II, pp. 173.

[20] Departemen Agama Republik Indonesia, Al-Qur'an dan Terjemahannya, Surabaya: Karya Utama, 1993, pp. 50.

[21] Departemen Agama Republik Indonesia, Al-Qur'an dan Terjemahannya, Surabaya: Karya Utama, 1993, pp. 810.

[22] Sawaluddin , Potensi Indra, Akal, dan Kalbu Menurut Al-Qur'an dan Aplikasinya Dalam Pengembangan Pendidikan Dasar, Pekanbaru: UIN Suska Riau, Disertasi, pp. 46.

[23] Muhaimin dan Abdul Mujib, Pemikiran Pendidikan Islam, Bandung: Trigenda, 1993, pp. 29.

[24] H. Zaini, Desain Pembelajaran Perguruan Tinggi, Yogyakarta: CTDS Sunan kalijaga, 2002, pp. 62.

[25] Sawaluddin, Potensi Indra, Akal, dan Kalbu Menurut Al-Qur'an dan Aplikasinya Dalam Pengembangan Pendidikan Dasar, Pekanbaru: UIN Suska Riau, Disertasi, pp. 366.

[26] Sawaluddin, Potensi Indra, Akal, dan Kalbu Menurut Al-Qur'an dan Aplikasinya Dalam Pengembangan Pendidikan Dasar, Pekanbaru: UIN Suska Riau, Disertasi, pp. 399 . 